\title{
Streptococcus sobrinus nom. rev. and Streptococcus ferus nom. rev.: Habitat of These and Other Mutans Streptococci
}

\author{
ALAN L. COYKENDALL \\ University of Connecticut, School of Dental Medicine, Farmington, Connecticut 06032
}

\begin{abstract}
Streptococcus sobrinus and Streptococcus ferus were not included on the Approved List of Bacterial Names in 1980. Type strains of these species are now available, and I propose that they be recognized. The available evidence indicates that $S$. ferus is a commensal of wild rats and that $S$. sobrinus and the other mutans streptococci (except $S$. ferus) are human commensals.
\end{abstract}

The members of the mutans group of streptococci were described in 1977 (6). Although the five species in this group are remarkably similar in overall biochemical and ecological characteristics $(12,25)$, their nucleic acid base contents $(3,11)$ and base sequences $(5,7)$ are too disparate to regard these streptococci as a single species. Three species in this group appear on the Approved Lists of Bacterial Names (28). These are Streptococcus mutans, Streptococcus rattus, and Streptococcus cricetus. Two species, Streptococcus sobrinus and Streptococcus ferus, were not accepted as approved species, probably because type strains were not available from recognized type culture collections. As a result, $S$. ferus and $S$. sobrinus currently have no standing in taxonomy.

Type strains of $S$. ferus and $S$. sobrinus are now available from the American Type Culture Collection, and I propose that $S$. ferus and $S$. sobrinus be added to the Approved Lists as revived species according to Rule $28 \mathrm{~A}$ of the International Code of Nomenclature of Bacteria (23).

Streptococcus sobrinus nom. rev. (i) Description. S. sobrinus (basionym, $S$. mutans subsp. sobrinus Coykendall [5]; so.bri'nus., L. masc. n. sobrinus male cousin on mother's side, referring to the distant relationship between this species and $S$. mutans) cells are gram-positive cocci 0.5 $\mu \mathrm{m}$ in diameter that occur in pairs and chains, which are often long. Mannitol and sorbitol are fermented; raffinose and melibiose are not. An adhesive glucan is produced from sucrose. Growth is enhanced in an atmosphere containing a reduced oxygen content. Ammonia is not produced from arginine. Colonies on agar containing sucrose are about $1 \mathrm{~mm}$ in diameter, rough, and heaped and often have droplets of liquid (containing glucan) at the top or the border. Hydrogen peroxide is produced. The deoxyribonucleic acid (DNA) base content is 44 to $46 \mathrm{~mol} \%$ guanine plus cytosine $(\mathrm{G}+\mathrm{C})$. (ii) Type strain. Strain SL1 (= ATCC 33478) is the type strain (5). This strain was isolated from a human mouth and was first mentioned by Fitzgerald and Jordan (14), but was not described by them. Strain $\mathrm{SL1}^{\mathrm{T}}$ ( $\mathrm{T}=$ type strain) produces acid from mannitol and sorbitol, but not from raffinose or melibiose; it does not split arginine (5). Perch et al. (25) reported that strain SL1 ${ }^{\mathrm{T}}$ is alpha-hemolytic on horse blood agar, produces $\mathrm{H}_{2} \mathrm{O}_{2}$, and does not grow at $45^{\circ} \mathrm{C}$. Its base content is $45.1 \mathrm{~mol} \% \mathrm{G}+\mathrm{C}$ as determined by thermal denaturation (3) and $44.9 \mathrm{~mol} \% \mathrm{G}+\mathrm{C}$ as determined by density in $\mathrm{CsCl}(11)$.

(iii) Additional comments. Electron micrographs of $S$. sobrinus strains K1R (8), 6715 (24), and OMZ176 (18) show cocci with an outer dendritic layer or fuzz, which has not been observed in $S$. mutans, $S$. rattus, or $S$. cricetus. Most $S$. sobrinus strains react with Bratthall antiserum $d$ (1). Some strains do not give a strong antiserum $d$ reaction, and these strains have been put into a separate serotype, designated serotype $g$ by Perch et al. (25). Strain SL1 ${ }^{\mathrm{T}}$ does not react with either group $d$ or group $g$ antibody. S. sobrinus strains SL1, K1R, and OMZ176 (5), as well as strains $14 \mathrm{H}, \mathrm{O} 1$, and $1 \mathrm{C}$ (7), share extensive common DNA base sequences. Some strains do not ferment sorbitol $(5,25)$, and strain $14 \mathrm{H}$ ferments neither sorbitol nor mannitol (7). S. sobrinus cells appear to be incapable of synthesizing or catabolizing significant amounts of intracellular polysaccharide (15). The habitat of S. sobrinus is the surface of human teeth $(2,25)$.

Streptococcus ferus nom. rev. (i) Description. $S$. ferus (fer'us. L. adj. ferus wild, referring to the wild rats from which the organism was isolated) cells are gram-positive cocci $0.5 \mu \mathrm{m}$ in diameter that occur in pairs and chains. Mannitol and sorbitol are fermented; raffinose is not. An adhesive glucan is produced from sucrose. This species is intolerant of $45^{\circ} \mathrm{C}$ or $6.5 \% \mathrm{NaCl}$. Ammonia is not produced from arginine. Colonies on 
agar containing sucrose are about $1 \mathrm{~mm}$ in diameter, raised, and somewhat adherent, with no liquid on or around the colony. The final $\mathrm{pH}$ in $1 \%$ glucose broth is 4.2 to 4.5 . The DNA base content is 43 to $45 \mathrm{~mol} \% \mathrm{G}+\mathrm{C}(9)$.

(ii) Type strain. The type strain is strain $8 \mathrm{~S} 1$ (9) (= ATCC 33477), which conforms to the description given above.

(iii) Additional comments. $S$. ferus was isolated in Florida from the mouths of wild rats that ate sugarcane (9) and from rats living in a landfill dump in Hartford, Conn. (7). Strains from the two locales were homologous as determined by DNA hybridization (7). Strains of $S$. ferus react with Bratthall antiserum $c$, although they are not related (as determined by DNA homology) to $S$. mutans (7). S. ferus strains do not grow on agar containing bacitracin $(0.2 \mathrm{U} / \mathrm{ml})$. The cells produce and catabolize intracellular polysaccharide (15). S. ferus has not been isolated from humans.

Despite their many similarities, the five mutans streptococcal species can be readily identified by biochemical or serological differences $(1$, $5,6,25$ ) (Table 1). It is interesting that some authors, although expressing reservations about the taxonomic separation of $S$. mutans, nevertheless point out the biochemical, serological, and genetic heterogeneity of $S$. mutans and remark on the good correlation among serotypes, biotypes, and genotypes $(16,20,25)$. That such clearly separable and genetically different organisms should all be called $S$. mutans seems unwarranted in light of modern taxonomic objectives (6).

Habitats of the mutans streptococci. There is also considerable confusion about the origins and natural habitats of the various mutans streptococcal species. Because $S$. cricetus and $S$. rattus are not common in humans, it has been suggested that the natural habitats of these organisms are animals (19). Conversely, it has been suggested that $S$. ferus, which was found in wild rats, was transmitted to rats by humans (26).

Although $S$. cricetus was originally isolated from a laboratory hamster, it is very likely that laboratory animals carry human commensals, especially if they are fed sucrose diets. Since the oral flora of wild hamsters is unknown and since $S$. cricetus has been found in humans in various geographic areas $(2,22,25)$, it seems reasonable to think of this species as a human commensal.

The case of $S$. rattus is similar. This organism was originally isolated from a laboratory rat, and it is likely that the organism was acquired from humans. Although this species is rare in humans, it has been found in scattered populations around the world $(2,17,22)$. Moreover, wild rats examined in Florida and Connecticut did not harbor $S$. rattus. It was in these rats that $S$. ferus was discovered (9). Since $S$. ferus has not been reported in humans, it is unlikely that these rats acquired $S$. ferus from humans, as has been speculated (26).

The available evidence from zoo animals indicates that mutans streptococci are not common among animals (10). Although Dvarskas and Coykendall (J. Dent. Res. 54(Special Issue A):127, 1975) stated that " 'S. mutans' was more widespread than expected," the statement referred to the fact that the wild rat strains (now $S$. ferus) of Florida were also found in Connecticut rats that scavenged a low-sucrose diet, and these authors would agree with Dent et al. (10) that except for $S$. ferus in rats, the mutans streptococci are not widely distributed in animals. Thus, it seems reasonable to regard $S$. cricetus and $S$. rattus, in addition to $S$. mutans and $S$. sobrinus, as human oral organisms.

TABLE 1. Differentiating characteristics of the members of the mutans group of streptococci ${ }^{a}$

\begin{tabular}{|c|c|c|c|c|}
\hline Species & $\begin{array}{l}\mathrm{G}+\mathrm{C} \text { content of } \\
\text { DNA }(\mathrm{mol} \%)^{b}\end{array}$ & $\begin{array}{l}\text { Serological } \\
\text { reaction }(\mathrm{s})^{c^{\prime}}\end{array}$ & Cell wall carbohydrates ${ }^{d}$ & $\begin{array}{l}\text { Biochemical characteristics useful } \\
\text { in identification }\end{array}$ \\
\hline S. mutans & $36-38$ & $c, e, f$ & Glucose, rhamnose & \\
\hline S. rattus & $41-43$ & $b$ & Galactose, rhamnose & $\begin{array}{l}\text { Produces ammonia from arginine; } \\
\text { grows at } 45^{\circ} \mathrm{C}\end{array}$ \\
\hline S. cricetus & $42-44$ & $a$ & Glucose, galactose, rhamnose & Susceptible to bacitracin \\
\hline S. sobrinus & $44-46$ & $d, g$ & Glucose, galactose, rhamnose & $\begin{array}{l}\text { Does not ferment raffinose; produces } \\
\mathrm{H}_{2} \mathrm{O}_{2}{ }^{f}\end{array}$ \\
\hline S. ferus & $43-45$ & $c$ & Not known & $\begin{array}{l}\text { Does not ferment raffinose; suscep- } \\
\text { tible to bacitracin }\end{array}$ \\
\hline
\end{tabular}

${ }^{a}$ All species ferment glucose, fructose, sucrose, trehalose, mannitol, and sorbitol and produce glucans from sucrose. See reference 6 for descriptions of $S$. mutans, $S$. rattus, and $S$. cricetus. For the results of extensive biochemical tests see references 12,13 , and 25 .

${ }^{b}$ Data from references 3 and 11 .

c Data from reference 1.

${ }^{d}$ Data from reference 21 .

${ }^{e}$ Data from reference 27.

${ }^{f}$ Data from reference 25. 


\section{LITERATURE CITED}

1. Bratthall, D. 1970 . Demonstration of five serological groups of streptococcal strains resembling Streptococcus mutans. Odontol. Revy 21:181-196.

2. Bratthall, D. 1972. Demonstration of Streptococcus mutans strains in some selected areas of the world. Odontol. Revy 23:401-410.

3. Coykendall, A. L. 1970. Base composition of deoxyribonucleic acid isolated from cariogenic streptococci. Arch. Oral Biol. 15:365-368.

4. Coykendall, A. L. 1971. Genetic heterogeneity in Streptococcus mutans. J. Bacteriol. 106:192-196.

5. Coykendall, A. L. 1974. Four types of Streptococcus mutans based on their genetic, antigenic, and biochemical characteristics. J. Gen. Microbiol. 83:327-338.

6. Coykendall, A. L. 1977. Proposal to elevate the subspecies of Streptococcus mutans to species status, based on their molecular composition. Int. J. Syst. Bacteriol. 27:26-30.

7. Coykendall, A. L., D. Bratthall, K. O'Connor, and R. A. Dvarskas. 1976. Serological and genetic examination of some nontypical Streptococcus mutans strains. Infect. Immun. 14:667-670.

8. Coykendall, A. L., O. P. Daily, M. J. Kramer, and M. E. Beath. 1971. DNA-DNA hybridization studies of Streptococcus mutans. J. Dent. Res. 50:1131-1139.

9. Coykendall, A. L., P. A. Specht, and H. H. Samol. 1974. Streptococcus mutans in a wild sucrose-eating rat population. Infect. Immun. 10:216-219.

10. Dent, V. E., J. M. Hardie, and G. H. Bowden. 1978. Streptococci isolated from dental plaque of animals. J. Appl. Bacteriol. 44:249-258.

11. Dunny, G. M., T. Hausner, and D. B. Clewell. 1972. Buoyant densities of DNA from various strains of Streptococcus mutans. Arch. Oral Biol. 17:1001-1003.

12. Edwardsson, S. 1968 . Characteristics of caries-inducing human streptococci resembling Streptococcus mutans. Arch. Oral Biol. 13:637-646.

13. Facklam, R. R. 1974. Characteristics of Streptococcus mutans isolated from human dental plaque and blood. Int J. Syst. Bacteriol. 24:313-319.

14. Fitzgerald, R. J., and H. V. Jordan. 1968. Polysaccharideproducing bacteria and caries, p. 79-86. In R. S. Harris (ed.), Art and science in dental caries research. Academic Press, Inc., New York.

15. Freedman, M. L., and A. L. Coykendall. 1975. Variation in the internal polysaccharide synthesis among Streptococcus mutans strains. Infect. Immun. 12:475-479.

16. Gehring, F. J. 1981. The genus Streptococcus and dental diseases, p. 1598-1613. In M. P. Starr, H. Stolp, H. G. Trüper, A. Balows, and H. G. Schlegel (ed.), The prokaryotes. A handbook on habitats, isolation, and identification of bacteria. Springer-Verlag, New York.

17. Guggenheim, B. 1968. Streptococci of dental plaques Caries Res. 2:147-163.

18. Guggenheim, B., K. G. König, and B. Regolati. 1969 Modifications of the oral bacterial flora and their influence on dental caries in the rat. III. The cariogenicity of an erythromycin-resistant strain of Streptococcus mutans compared to its non-resistant parent strain. Helv. Odontol. Acta 13:13-22.

19. Hamada, S., N. Masuda, and T. Shimamoto. 1979. Some biological properties of Streptococcus mutans isolated from human mouths, with reference to the correlation with serotypes. Arch. Oral Biol. 24:627-631.

20. Hamada, S., and H. D. Slade. 1980. Biology, immunology, and cariogenicity of Streptococcus mutans. Microbiol Rev. 44:331-384.

21. Hardie, J. M., and G. H. Bowden. 1974. Cell wall and serological studies of Streptococcus mutans. Caries Res. 8:301-316.

22. Keene, H. J., I. L. Shklair, G. J. Mickel, and M. R. Wirthlin. 1977. Distribution of Streptococcus mutans biotypes in five human populations. J. Dent. Res. 56:5-10.

23. Lapage, S. P., P. H. A. Sneath, E. F. Lessel, V. B. D. Skerman, H. P. R. Seeliger, and W. A. Clark (ed.). 1975 International code of nomenclature of bacteria. $1975 \mathrm{Revi}$ sion. American Society for Microbiology, Washington, D.C.

24. Nalbandian, J., M. L. Freedman, J. M. Tanzer, and S. M. Lovelace. 1974. Ultrastructure of mutants of Streptococcus mutans with reference to agglutination, adhesion, and extraceilular polysaccharide. Infect. Immun. 10:1170_ 1179

25. Perch, B., E. Kjems, and T. Ravn. 1974. Biochemical and serological properties of Streptococcus mutans from various human and animal sources. Acta Pathol. Microbiol Scand. Sect. B 82:357-370.

26. Shklair, I. L. 1981 . Natural occurrence of caries in animals-animals as vectors and reservoirs of cariogenic flora, p. 41-48. In J. M. Tanzer (ed.), Animal models in cariology (a special supplement to Microbiology Abstracts). Information Retrieval, Inc., Washington, D.C.

27. Shklair, I. L., and H. J. Keene. 1974. A biochemical scheme for the separation of the five varieties of Streptococcus mutans. Arch. Oral Biol. 19:1079-1081.

28. Skerman, V. B. D., V. McGowan, and P. H. A. Sneath (ed.). 1980. Approved lists of bacterial names. Int. J. Syst. Bacteriol. 30:225-420. 